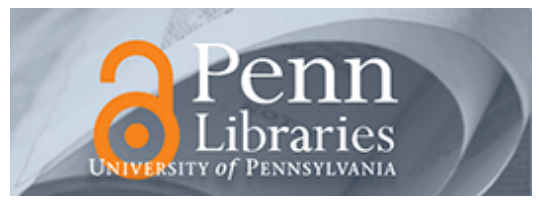

University of Pennsylvania ScholarlyCommons

Marketing Papers

Wharton Faculty Research

2007

\title{
Forecasting of Software Development Work Effort: Introduction
}

\author{
J. Scott Armstrong \\ University of Pennsylvania, armstrong@wharton.upenn.edu
}

Follow this and additional works at: https://repository.upenn.edu/marketing_papers

Part of the Marketing Commons

\section{Recommended Citation}

Armstrong, J. S. (2007). Forecasting of Software Development Work Effort: Introduction. Retrieved from https://repository.upenn.edu/marketing_papers/158

Suggested Citation:

Armstrong, J.S. (2007). Forecasting of Software Development Work Effort: Introduction. International Journal of Forecasting. Vol. 23(3). p. 447.

Publisher URL: http://dx.doi.org/10.1016/j.iforecast.2007.05.014

This paper is posted at ScholarlyCommons. https://repository.upenn.edu/marketing_papers/158

For more information, please contact repository@pobox.upenn.edu. 


\section{Forecasting of Software Development Work Effort: Introduction}

\section{Disciplines}

Business | Marketing

\section{Comments}

\section{Suggested Citation:}

Armstrong, J.S. (2007). Forecasting of Software Development Work Effort: Introduction. International Journal of Forecasting. Vol. 23(3). p. 447.

Publisher URL: http://dx.doi.org/10.1016/j.iforecast.2007.05.014 


\title{
Forecasting of Software Development Work Effort: Introduction
}

\author{
J. Scott Armstrong \\ The Wharton School, University of Pennsylvania \\ This paper was published in the \\ International Journal of Forecasting, 23, 2007, p 447
}

Jørgensen's paper examines the application of the one of the most well established findings in forecasting - - namely, the superior accuracy of quantitative models in comparison to judgmental forecasts. Models improved accuracy in $72 \%$ of the 136 studies in the meta-analysis by Grove, et al. (2000). However, in Jørgensen’s metaanalysis, restricted to forecasts of software effort, models were superior for only $38 \%$ of the studies.

Jørgensen examines what happens when practitioners use quantitative models to forecast how long it takes to complete software development projects. Forecast errors in this area tend to be large, so improvements would be of great practical value. But his paper and the commentaries are also important for the more general topic of how to implement new forecasting methods most effectively.

The main paper by Jørgensen went through a review process that led to many revisions. Once accepted in 2005, the paper was scheduled for discussion at the International Symposium on Forecasting in Santander, Spain, in June 2006. This led to further revisions. The commentaries from the symposium were also subjected to peer review and these are published along with the main paper.

Jørgensen did an excellent job of searching for relevant studies and in summarizing their findings. To ensure that he properly quoted the authors in the meta-analysis, he contacted each of them. This is a key issue because, as shown in Wright and Armstrong (2007), it is common for papers to be misquoted.

The findings were unexpected. On average, there was no gain. What is going on? There are two practical considerations. First, the conditions might have been unfavorable to the use of quantitative models, And, second, the quantitative models may not have been properly implemented.

Jørgensen’s analysis revealed that many of the studies on software work effort did not report fully on the conditions. Journals should insist on full disclosure. There is no longer any excuse that space is limited; details can be provided on the Internet.

Details were also lacking in many studies as to the implementation of the procedures. The procedures seem critical. For example, in many of the studies, the forecasts were not separated from the planning process. That is, the planners/decision makers made the forecasts, and then they had the ability to modify the inputs to achieve the desired results. 
The commentators address key issues involved in using important findings for practical problems.

\section{Reference}

Grove, W.M., Zald, D.H., Lebow, B.S., Snitz, B.E., \& Nelson, C. (2000). “Clinical versus mechanical prediction: A meta-analysis,” Psychological Assessment, 12 (1), 1930 .

Wright, Malcolm \& J. Scott Armstrong (2007), "Verification of citations: Fawlty Towers of knowledge?” Interfaces xx, xx-xx. 